\title{
USE OF THE TOYOTA MANAGEMENT PRINCIPLES FOR EVALUATION OF THE COMPANY'S MISSION
}

\author{
Jacek Selejdak $^{1 *}$ \\ ${ }^{1}$ Institute of Production Engineering, Faculty of Management, Częstochowa University of Technology, \\ Al. Armii Krajowej 19B, 42-201 Czestochowa, Poland \\ * corresponding author: Tel.: +48 3432503 67, e-mail: jacek.s@zim.pcz.pl
}

\section{Resume}

In the paper there were described the elements of the Toyota roof. Electroacoustic products were characterized. Immaterial resources of the company were analyzed. To do so, the BOST survey, whose questionnaires were filled in by employees of the chosen enterprise, was used. Particular attention was paid to the following factors: quality, costs, lead time, work safety and personnel morale.

Available online on April 2013: http://www.qpij.pl/

\author{
Article info \\ Article history: \\ Received 05 September 2013 \\ Accepted 04 November 2013 \\ Keywords: \\ BOST, \\ principle of Toyota management \\ validity ranks
}

\section{Introduction}

The resarch was conducted in a company which produces electroacoustic goods. Electroacoustic products called the electric appliances band whose purpose is to process acoustic signals into electrical signals and vice versa (SEREDA J. 1981). The main groups of electroacoustic products are microphones, sound recorders, audio players, audio amplifiers, speakers and speaker units that significantly affect the subjectively perceived sound quality. With the current level of digital audio recording and high-quality players, there are not many problems with the poor quality of the source audio as it was in the case of magnetic or analog media. So the quality of the speakers and the speaker teams significantly affect the quality of the reproduction of their sound. The main element of the speaker system is the same speaker, the electroacoustic transducer, whose task is to change the electricity supplied to the amplifier into an acoustic wave. It uses a coil placed in the magnetic field of the permanent magnet pole piece through which alternating current flows via the amplifier, causing the speaker cone excursion in both directions from the equilibrium position. Cone excursion causes air thickening before the membrane and retraction causes dilution resulting in a wave of sound that reaches the ear of the recipient (KRAJEWSKI J. 2003).

\section{Research methodology}

Information on the importance of quality and its control has been obtained on the basis of surveys conducted in the area of E1 among employees. A set of factors for E1 area for the principle one of Toyota management (BORKOWSKI S., KRYNKE M. 2011, BORKOWSKI S., KNOP K. 2010). Respondents in the E1 answered the following question in the survey BOST (BORKOWSKI S. 2012a, BORKOWSKI S. 2012b, BORKOWSKI S. 2012c):

What is most important in your company? In the box, type 1, 2, 3, 4, 5 (5 the most important factor).

\begin{tabular}{|c|c|}
\hline JA & Quality \\
\hline $\mathrm{KO}$ & Costs \\
\hline CR & Lead time \\
\hline $\mathrm{BP}$ & Work safety \\
\hline MZ & Personnel morale \\
\hline
\end{tabular}


Tables 1 and 2 show the numbers and percentages of factors statement in validity assessment area of the roof of the Toyota house in the enterprise engaged in the production of sound equipment (BORKOWSKI S. 2012a, BORKOWSKI S. 2012c, LIKER J.K. 2005).

Table 1. Numerical combination of the factors importance evaluation for area of the Toyota roof elements

\begin{tabular}{c|ccccc}
\hline \multirow{2}{*}{ Evaluation } & \multicolumn{5}{|c}{ Indicating the factors } \\
\cline { 2 - 6 } & JA & KO & CR & BP & MZ \\
\hline 1 & 0 & 0 & 0 & 0 & 23 \\
2 & 0 & 0 & 0 & 23 & 0 \\
3 & 5 & 3 & 15 & 0 & 0 \\
4 & 4 & 16 & 3 & 0 & 0 \\
5 & 14 & 4 & 5 & 0 & 0 \\
\hline
\end{tabular}

Source: own study

Table 2. Evaluation structure [\%] of the factors importance for area of the Toyota roof elements

\begin{tabular}{c|ccccc}
\hline \multirow{2}{*}{ Evaluation } & \multicolumn{5}{|c}{ Indicating the factors } \\
\cline { 2 - 6 } & JA & KO & CR & BP & MZ \\
\hline 1 & 0.0 & 0.0 & 0.0 & 0.0 & 100.0 \\
2 & 0.0 & 0.0 & 0.0 & 100.0 & 0.0 \\
3 & 21.7 & 13.0 & 65.2 & 0.0 & 0.0 \\
4 & 17.4 & 69.6 & 13.0 & 0.0 & 0.0 \\
5 & 60.9 & 17.4 & 21.7 & 0.0 & 0.0 \\
\hline
\end{tabular}

Source: own study

\section{Validity of ranks}

In Figure 1 there is presented the importance of each factor using Pareto - Lorenz diagrams (BORKOWSKI S. 2004, SELEJDAK J., BORKOWSKI S. 2004).

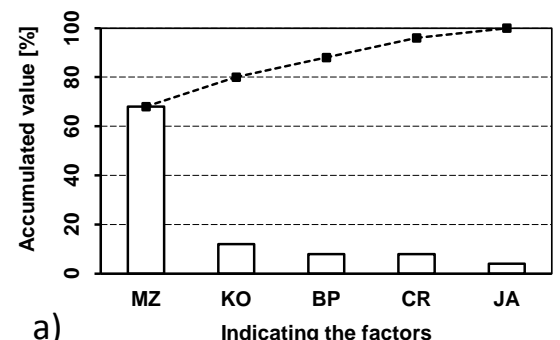

a)

Indicating the factors
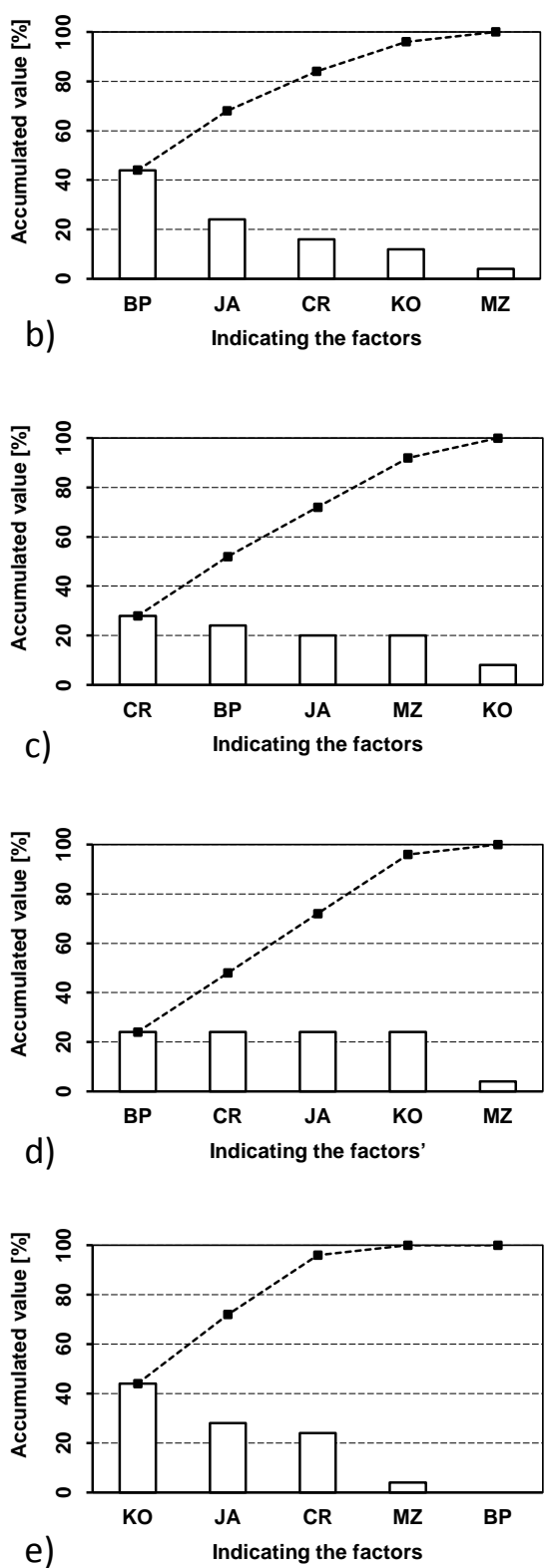

Fig. 1. Pareto-Lorenz diagrams of the factors importance area of the Toyota roof elements for evaluations: a) „, 1”, b) „2”, c) „3”, d) ,4”, e) ,5”. Applies to company manufacturing electroacoustic equipment

Source: own study

The least important factor for the staff was personnel morale (MZ). 68\% of the lowest ratings coincided precisely for this factor. The rest of the factors shared values between $4 \%$ and $12 \%$.

In the case of evaluation 2, the dominance is not as clear. Work safety factor (BP) was $44 \%$, quality (I) $24 \%$, lead time (CR) $16 \%$, costs (KO) $12 \%$, personnel morale (MZ) $4 \%$. 
For the assessment of " 3 ", the values are more aligned, most of the factors received around $20 \%$ of the vote. Only factor costs (KO) was $8 \%$.

All the factors except personnel morale (MZ) received $24 \%$ of ratings “4”, personnel morale factor (MZ) got $4 \%$ of all rated " 4 ".

For the assessment of "5" factor costs (KO) has a big advantage over the other factors. Quality factor (I) received $28 \%$ of votes, while the execution time factor (CR) 24\%. Personnel morale factor (MZ) received only $4 \%$ of the highest ratings, and the work safety factor (BP) showed no assessment of the fifth

Analysis of Pareto - Lorenzo diagrams has revealed that the most important factors in the company are quality (JA) and costs (KO). Execution time factor (CR) is also often chosen as important, but smaller number of people considered it to be the most important.

The data presented in Figure 1 was used to build the ranks of the validity factors for the area of elements of the Toyota roof:

- rating " 1 ”

$$
M Z>K O>(B P, C R)>J A
$$

- rating "2"

$$
B P>J A>C R>K O>M Z
$$

- rating " 3 "

$$
C R>B P>(J A, M Z)>K O
$$

- rating " 4 "

$$
(B P, C R, J A, K O)>M Z
$$

- rating “ 5 ”

$$
K O>J A>C R>M Z>B P
$$

\section{- average}

$$
J A>K O>C R>B P>M Z
$$

\section{Summary}

The object of the research was a company producing electroacoustic products. BOST testing confirmed a high awareness among employees regarding quality as an important parameter.
A large number of employees also acknowledge the importance of costs. These are quite optimistic conclusions as the crew seems to be aware of the new developments, changes and shows a greater desire for training. However, it may be disturbing they ignore the fact of safety. After all, in the company there are used quite dangerous tools that can easily lead to accidents, and consequently, ruin the health of workers. It would be worthwhile to draw employees' attention to work safety and take steps to reduce the risk of accidents.

\section{References}

[1] BORKOWSKI S. 2004, Mierzenie poziomu jakości, Wydawnictwo Wyższej Szkoły Zarządzania i Marketingu w Sosnowcu, Sosnowiec.

[2] BORKOWSKI S. 2012a, Dokumenty zawierające wymyślony termin (TOYOTARYZM) oraz zawierające nazwę i strukturę opracowanej metody (BOST). Potwierdzenie daty. „AAK” Kancelaria Patentowa s.c. Częstochowa.

[3] BoRKOWSKI S. 2012b, Toyotaryzm. Wyniki badań BOST, Wydawnictwo Menedżerskie PTM, Warszawa.

[4] BORKOWSKI S. 2012c, Zasady zarzadzania Toyoty $w$ pytaniach. Wyniki badań BOST, Wydawnictwo Menedżerskie PTM, Warszawa.

[5] BoRKOWSKI S., KNOP K. 2010, Archives of Foundry Engineering Vol. 10 Special Issue (1) 11-16.

[6] BORKOWSKI S., KRYNKE M. 2011, Improvement of Production Processes, TRIPSOFT, Trnava.

[7] KRAJEWSKI J. 2003, Głośniki i zestawy głośnikowe budowa działanie zastosowania, Wydawnictwa Komunikacji i Łączności, Warszawa.

[8] LIKER J.K. 2005, Droga Toyoty.14 zasad zarzadzania wiodacej firmy produkcyjnej świata, Wydawnictwo MT Biznes, Warszawa.

[9] SELEJDAK J., BORKOWSKI S. 2004, In: Advanced manufacturing and repair technologies in vehicle industry. $21^{\text {st }} \quad$ International Colloquium Balatonfured, Hungary, pp. 18-22.

[10] SEREDA J. 1981, Pomiary w elektroakustyce. WKiŁ, Warszawa. 